\title{
BILDUNGSROMAN FOR CHARACTER EDUCATION IN HIGHER EDUCATION: AN INDONESIAN CONTEXT
}

\author{
Nita Novianti \\ Universitas Pendidikan Indonesia \\ nitanoviantiwahyu@upi.edu
}

First draft received: 10 November 2016

Final proof received: 18 February 2017

\begin{tabular}{|l}
\hline \hline Abstract \\
Considering the lack of research on character education in higher education, this paper proposes that \\
Bildungsroman, a genre concerned with a protagonist's development and education from childhood to \\
adulthood, fits perfectly into the recent need of literary works for teaching character education in college. \\
Employing literature review, this paper argues that Bildungsroman satisfies the major requirements for \\
literary works for character education in college drawn from O'Sullivan (2004). Bildungsroman also \\
provides a rich source for cultivation of character traits as stipulated by the Indonesian Department of \\
National Education (2010). Furthermore, the general theme of self-development is highly appropriate to \\
the nature of character education in higher education, namely as a continuation and consolidation of the \\
character developed in college students' previous education. It is expected that the present study will \\
contribute to the teaching of character education through literature, although further studies are required \\
in order to explore the effective teaching and learning techniques. \\
Keywords: Bildungsroman; character education; higher education; literature. \\
To cite this paper (in APA style): \\
Novianti, N. (2017). Bildungsroman for character education in higher education: An Indonesian context. \\
International Journal of Education, 9(2), 126-132 doi: dx.doi.org/10.17509/ije.v9i2.5474
\end{tabular}

\section{INTRODUCTION}

Character education has recently has regained its importance in the world of education. It is, according to Lickona, (1991: p. 6) is "as old as education itself," where "down through history, in countries all over the world, education has had two great goals: to help young people become smart, and to help them become good." Indeed, the importance of character education has been perceived throughout the times in various parts of the world, possibly with different labels and with fluctuating emphasis, where at times it can be highlighted and promoted in an exclusive curriculum, and other times, it is embedded or implicitly included in the existing curricula (Lickona, 1991; Russel, 2012; Watz, 2011). In the United States, character education gained its momentum in the early 1990s and was echoed by the Great Britain later in the same decade (Davison in Bohlin, 2005).

Meanwhile, in Indonesian context, character education has again come to be the concern of the nation in line with the increasingly perceived moral degradation and the fading sense of nationalism among Indonesian youths (Gunarti, 2013; Kanzunnudin, 2012). This issue of moral degradation that underpins the importance of character education is shared by other countries, such as the US and UK, where in Bohlin's words, the two countries have "a shared sense of urgency, a concern to respond swiftly to the growing "litany of alarm"' (p. 1). The urgency of moral issues among the younger generations has prompted the two countries and Indonesia as well to seek solutions in character education.

In Indonesia, character education was imposed by the government in the form of Ministry's
Regulation in 2009, followed by the Ministry of Culture and Education's formulation of a curriculum for character education and the list of character traits to be developed. Character education was then officiated with the Declaration of National Culture and Character Education as a national movement in January 2010 and further asserted by the then President Susilo Bambang Yudhoyono in the commemoration of National Education Day on May 2, 2010. From that time onwards, character education has been formulated in the 2013 curriculum that is alternatively called the curriculum of character education, emphasizing three main aspects, namely character, knowledge, and skill. Character education has since been integrated into all subjects at all school levels.

Since its inclusion in all subjects-in other words, character education no longer exclusively belongs to religious or moral education-the incorporation of character education into various subjects has been explored and researched, with literature being in no exception. Unfortunately, despite the increasingly perceived importance of literature for character education, most research on the integration of literature and character education has exclusively focused on primary and secondary school students (Brynildssen, 2002; Ikhwan, 2013; Nurgiyantoro, 2010; Klein-Ezell et al., 2014; Kusmarwantini, 2012; Olaniyan-Shobowale, 2016; Tyra, 2012), leaving a gap in research on character education for higher education students.

Indeed, character education in higher education is not as well-established as is that in primary and secondary schools. Findings from Silay's research (2013), for example, reveal that university academics 
in general agree that character education does not take place in universities. Her findings are reciprocal to those of Kuh and Umbach (2004), who reported that "some argue that the values and ethical systems of individual students are pretty well set before they come to college" (38), thereby creating a misconception that college or higher education is not responsible for teaching character education to students. Attesting to the perceived resistance of colleges towards the implementation of character education, Schwartz (2000, p. A68) put forward several misconceptions concerning character education for college students, namely: "1) A person's character is formed by the time he or she gets to college; 2) Colleges, and especially faculty members, aren't in the business of fostering character; and 3) The term 'character' is a code word for religious or conservative ideology." These three misconceptions have to some extent justified colleges' resistance to implement character education.

Nevertheless, the importance of character education in higher education has been increasingly perceived, especially in Indonesia (Farida, 2012). Advocates of character education in Indonesia, such as Dharmawan $(2014$, p. 9), argued that based on the holistic approach, character education has to be implemented continually, so that the moral values already cultivated in children will not be halted in their development at a certain school level or age. Furthermore, as Kuh \& Umbach (2004) explained, '[T]he college experience can at the least accentuate a student's values development trajectory ...., college can further support and channel maturational processes under way to crystallize and integrate the attitudinal and values dimension of a student's identity' (p. 38). Hence, the continuation of character education in higher education is necessary in order to preserve and strengthen the character that has been shaped in the previous schools.

As many researchers and educational experts have come to stress the importance of character education in college, research on literature for character education in college has consequently gradually increased in number. However, compared to research on the same topic in primary and secondary schools, it can be said that research on the same topic in college is still far from satisfactory. Moreover, there seem to be very few, not to say nonexistent, explorations and analyses of what genres, and more specifically which literary works, best suit the purposes of teaching character education in college. This is highly contrary to the well-established position of children's and young adult literature in the teaching of character education in primary and secondary schools, where in fact, various works from these genres have been explored and analyzed for their potential values that are in accordance with the values encouraged by the government to be instilled in primary and secondary school students, which in Indonesian case will be those formulated by the Department of National Education.

Departing from these gaps, the present study proposes the use of Bildungsroman genre to teach character education at the level of college, especially in Indonesian context. The considerations for selecting the genre will be provided, by looking at the literature of Bildungsroman and taking into account the process of appropriate book selection for character education in higher education. It is argued that the use of Bildungsroman will ultimately serve the role of higher education in character education as stated by some scholars above, namely to continue and strengthen the character students have developed in their early schools and at home. Before further examining and exploring Bildungsroman for teaching character education, a review of previous research focusing specifically on teaching character education through literature in college will be presented.

\section{Teaching Character Education through Literature in College}

Although not as abundant as research on teaching character education through literature in primary and secondary schools, literature has recorded some researchers who devoted their work on the teaching of character education through literature in higher education. Tighe (1998) particularly focused on "the connection between the study of values and the development of critical thinking skills" (p. 57). Her research used Lois Lowry's The Giver and Michael Dorris' A Yellow Raft on Blue Water to find whether the teaching of values or character education through the activities of reading, writing, and discussing the works can both instill good values and improve high school and undergraduate students' critical thinking. As a result, her research found that even though there would be no guarantee that the students under research would incorporate the values found in the novels into their life, the literary activities "provide them with the critical thinking skills to analyze their own personal decisions and to evaluate the possible consequences of such actions" (59). It can be inferred that instilling values in students is not a process whose result can be obtained immediately, as it is largely believed that character education is and should be a life-long process, not limited to time and place. In addition, the findings imply that critical thinking is important in the process of instilling values through reading, writing, and discussing literary works, without which, the process of character education will not take place.

Meanwhile in Indonesia, Inderawati (2012) has attempted to develop literary appreciation instrument that can be adopted to build student character "based on [the idea of] the literature for all and literature across the curriculum" (p. 941). Drawing upon the theories of reader response, conditioning, psycholiterature, and character building as the framework, her research:

[P]roduces a valid, effective, and reliable
instrument for appreciating literary works to
develop the first semester students'
character at Sriwijaya University by reading
and appreciating certain kinds of literary
works on the Personality Development
course. The literary appreciation's
instrument is able to increase the
effectiveness of students' appreciation
result by achieving very good category with
the emerging of two or more such
indicator. (p. 943)

In short, her study proved that with an appropriate instrument, literature can be used not only to teach character education to language students, but also to non-language students at 
college level, while at the same time increasing students' literary appreciation in general.

While Inderawati promoted the idea of literature for all, Ripai (2012) has specifically developed thinkpair-share technique for the teaching and learning of writing drama script imbued with the values of character education to students of Indonesian language and literature education. His findings proved that the technique was applicable and able to fulfill the requirements of minimum criteria of completion for a subject or course. However, his research did not further examine whether the technique was effective in building the character of the research subjects, namely college students assigned to write drama scripts imbued with values of character education. Furthermore, he did not elaborate what values of character education can be found in the drama scripts produced by the students.

As the literature demonstrates, research focusing on the exploration of the kinds of literary works suitable for teaching character education in college has not been popular. In the case of Tighe, for instance, she did not explain the process of selecting the two novels used in her research. While it is true that almost all genres of literature can be used to teach character education to college students, depending on the techniques employed in teaching them; still, careful selection taking into account the specific nature of character education and college students themselves has to be done. This is in line with Parker and Ackerman's (2007) argument that "[b]ook selection is a critical element for successful character education" (p.1). It is the task of the lecturers or teachers to select books that best suit the objectives of teaching character education by considering the content of the book as well as the characteristics of their students. The discussion will not turn to the literature review of Bildungsroman.

\section{Bildungsroman Defined}

Defining a literary term is always an intricate business. Indeed, there has been a heated debate as to what constitutes a Bildungsroman. As Boes explained, 'the heuristic value of the Bildungsroman label has been disputed, defended, taken for granted, and otherwise muddled. The term is sometimes especially within English departments -used so broadly that seemingly any novel . . . might be subsumed by it' (2006, p. 230) (see also Iversen, 2009). Especially in the flourishing age of young adult literature, this genre is often claimed to have been merged and or included in literary works about youths entering adulthood and the problems they experience throughout the process, such as attested to by $\mathrm{Au}$, 'These 'coming of age' qualities have become popularized in other book genres that target towards youth and adolescent readers' (2011, p.3). For the purpose of this study, it is argued that Bildungsroman is a distinguished genre of literature. Some of its characteristics may have been merged in other genres, ultimately works categorized under the label of young adult literature. However, Bildungsroman has existed long before young adult literature established its position.

As the name suggests, Bildungsroman was first established in German Literature, even though one will argue that the genre existed elsewhere in the world even before it was given a fixed term in Germany. The dispute over the history of
Bildungsroman, which is called a "war" of history between 'the German Purists' and 'the International Pluralists" by Iversen $(2009$, p. 11) should also be dismissed for the intention of the present study. Rather than debating over the naming of a certain movement or phenomenon, it is far more important to focus on the phenomenon itself and its significance. In this light, Boes' recount of the history will come in handy. Regarding the coinage of this term, he explains, "The term 'Bildungsroman' was introduced to the critical vocabulary by the German philosopher and sociologist Wilhelm Dilthey (1833-1941)" (Boes, 2006, p. 231). He further explained that the genre has since then been defined as "a novel of formation" (2006, p. 232) or self-education, in which the character goes through the process of self-formation and or self-education.

The very first novel deemed to represent this genre is Goethe's Wilhelm Meister Apprenticeship. As the title indicates, the novel is about the apprenticeship of the main character, Wilhelm Meister. The Oxford Companion to English Literature describes the novel this way:

\begin{abstract}
Wilhelm provides the model of the innocent, inexperienced, well meaning, but often foolish and erring, young man who sets out in life with either no aim in mind or the wrong one. By a series of false starts and mistakes and with help from well-disposed friends he makes in the course of his experiences, he finally reaches maturity and finds proper profession. (p. 102)
\end{abstract}

As the introduction to the novel indicates, Bildungsroman is concerned with the development and formation of a character from innocence to experience, from childhood to adulthood. Jerome Buckley evinced that the term "bildung" invariably connotes a "portrait," "picture," "shaping," and "formation" (1974, p. 14). In addition, the term "bildung" has also been loosely defined as education. Thus, although there are variations and debates for the definition of Bildungsroman, this genre is undoubtedly one that is concerned with a character's education and development from childhood to adulthood. The ultimate characteristic of this genre will be the existence of character's development, both physically and (most importantly) psychologically.

The notion above is purported by a number of definitions provided by scholars and critics of Bildungsroman. To start with, Buckley (1974) stated, "the Bildungsroman in its pure form has been defined as a 'novel of all around development or self-culture' with a more or less conscious attempt on the part of the hero to integrate his powers, to cultivate himself by his experience" (p. 13). The key words here are development, self-culture, and experience. A more recent definition is offered by John $\mathrm{Au}$. He defined Bildungroman as a genre concerned with "the coming of age and rites of passage of an adolescent and/or young adult and is recognized for how it educates its readers about personal growth and selfconsciousness" (Au, 2011, p. 2). His definition stands out in that it highlights the nature of the genre as a form of education not only for the protagonist of the work, but also for the reader. In other words, his definition can be said to originate from the initial purpose of this genre that was born in the 
Enlightenment era, namely to educate the youth readers.

As Summerfield and Downward explained, "the designation Bildungsroman was first used by the critic Karl Morgenstern ... [ [who] clearly stated that the genre was to portray the hero's Bildung (formation) in all its steps and final goal as well as to foster the Bildung of the readers" $(2010$, p. 1$)$. In sum, the genre is about a youth as a protagonist venturing in a journey to educate and develop himself, as well as to broaden his horizon with new experiences and new values he encounters within the society where he lives, in order for him to later find his own position in the society as an adult.

The definitions offered above, on the other hand, show the apparent flaw of the genre, namely its exclusive focus on male protagonist. Fortunately, in its course of development, the genre has come to include female protagonists and even minority groups, such as the case in the contemporary American literature Braendlin (as cited in Chang et al., 2011), and that ethnic women writers have created a new Bildungsroman as a medium by which they can assert their own identity, instead of shaping the identity imposed by the patriarchal system. The emergence of female protagonists from the minority groups has enriched the repertoire of Bildungsroman, and in the case of character education, heightened its possibility to be used to teach character education.

Hence, in the list of works critics in general agree to subsume under this genre, such as, Charles Dickens's Great Expectations, Charlotte Bronte's Jane Eyre, James Joyce's Portrait of the Artist as a Young Man, J.D. Salinger's The Catcher in the Rye, S.E. Hinton's The Outsiders, and Harper Lee's To Kill a Mockingbird, one can find that Bildungsroman novels with female protagonists have been included. The list is certainly getting more expanded to include works, such as The Porcupine Year by Louise Erdrich, the Native American writer, and other works with female protagonists by writers of minority groups. Meanwhile, from the repertoire of Indonesian literature, works such as Hamka's Di Bawah Naungan Ka'bah, Hirata's Laskar Pelangi and its trilogy can be loosely categorized into the genre of Bildungsroman.

From the explanations given above, there seems to be one connecting thread of inference, namely Bildungsroman is a genre concerned with education-not only the education of the protagonist of a certain work, but also the education of the reader. With the undeniable role of Bildungsroman in the realm of education, employing this genre in the teaching of character education should be sufficiently justified. To gain a better understanding and more conviction on the proposition, the reasons for teaching character education to college students through Bildungsroman in a college class will be discussed in the following sections.

\section{Why Bildungsroman to Teach Character Education to College Students?}

Book selection for whatever purpose is never a simple task, more so in the case of character education. In this light, Sweeney (2008) stated, "As any avid reader knows, good literature explores the profound themes of humanity and gives us insight into human nature: growth and initiation, relationships and love, alienation and death. Literature is a delightful opportunity to unite academics and character education" (p.7). Any proponent of teaching character education will certainly agree with the statement. However, what constitutes 'good literature' remains under heated debate, to the extent that such a debate has become pointless. Hence, in this particular context, rather than selecting books based on the subjective formulations of what constitutes 'good books' or literary works in this case, it is better to select books for character education based on their suitability to college students' ages (thus, their psychological conditions) and the aims of character education itself, especially in Indonesian context, as formulated by the Ministry of National Education.

\section{Bildungsroman Suits the Key Characteristics of Books Appropriate for Character Education in College}

Drawing upon the theory proposed by O'Sullivan (2004), the present research will argue that Bildungsroman suits the four characteristics of books that are highly appropriate for character education. Although O'Sullivan postulates the characteristics in the context of children's literature, they can also be applied to books for college students as the readers. They are as follows:

- Well-written books containing moral dilemmas

- Books with enough depth to allow moving beyond literal comprehension

- Books with admirable but believable characters about the same age as students

- Books across a wide range of cultures and with both boys and girls as lead characters. (p. 641)

The four characteristics stress on the importance of content, in which it should be a neat combination of education and entertainment. The selected books should be light, yet at the same time invite readers to think critically of the problems or dilemmas presented, so as to gain in-depth understanding. The characters of the books should also be realistic and in the same range of age as the readers in order for identification to take place; even better, the books should allow the readers to relate to the characters and their story. In addition, the books should provide a range of variety of cultures for the students/readers to explore.

To start with, Bildungsroman is indeed a work with moral dilemmas as one of its main themes. The recurrent theme of the protagonists growing up and maturing through their encounter with moral dilemmas in order to finally find their own stance in the society is one of the remarkable characteristics of the genre. In her discussion of the issue of moral in English Bildungsroman, Brown (2013) has found that moral dilemma is one of the central themes of the genre, where, "'moral' is defined as dynamic and context-specific, residing not in a general, normative truth, but in the particulars of the lived experience" ( $p$. 675 ). It is clear then that the moral dilemmas faced by the protagonist of Bildungsroman are rooted from the fact that moral is not black-and-white, fixed and universal. Moral is something that is subject to the protagonist' view of life, the society's view wherein $\mathrm{s} /$ he lives, and the particular issue the protagonist is posed with.

In the same vein, teaching character education by means of presenting readers with stories laden 
with moral dilemmas is termed "moral judgment approach" (Prestwich, 2004, p. 142). This approach is indirect in its nature. Although the increasing moral problems among children and young adults in general have been made a strong basis to teach character education in a more direct approach, the moral judgment approach is still preferred. Interestingly, the nature of Bildungsroman is that it indeed 'educates' readers through the moral dilemmas undergone by the protagonist in a non-explicit way, nor it is preachy. It is arguable then that Bildungsroman is a novel of education, but it does not 'preach' readers. Bohlin (2005) has cautioned that "the most effective books are the least didactic" (p. 27). On a similar note, Au (2010) noted that stories are not written merely for pleasure, but also for education. His statement implies that while Bildungsroman aims to educate, it is basically a work from which readers will gain pleasure. Thus, it can be said that entertainment and education blend well in Bildungsroman.

The second point that has to be considered in selecting books for character education is the book's depth that allows for comprehension. In the context of character education, O'Sullivan's point can be translated as the books having the quality of evoking readers' critical thinking and reading of the issues the protagonists encounter. Readers should be able to see the depth of issues, not just the surface. In this light, Au (2010) stated:

In order for the novels to educate its readers, the genre must inform them through several literary aspects: psychological, social and cultural, philosophical and aesthetical, and historical. The focus is not aimed towards the surrounding circumstances and problems, but towards the protagonist's personal growth and development. (p. 4)

$\mathrm{Au}$ basically believes that readers should understand the protagonist's self-formation from several dimensions, or what he terms 'literary aspects', namely 'psychological, social and cultural, philosophical and aesthetical, and historical.' In other words, the protagonist's development does not take place in a single and closed entity; it involves various aspects of life. Understanding this issue demands readers' in-depth understanding through critical thinking to see the underlying aspect and various dimensions affecting one's development.

The third point is the books should have 'admirable but believable characters about the same age as the students.' This point means that books for character education should have characters that are at the same age as the target audiences, namely the students. In the case of character education in college, college students are usually those at the age of 17-25. Especially in Indonesian case, in which not many adult learners return to college, college students are mostly at the aforementioned range of ages. Indeed, as the definition of Bildungsroman denotes, the protagonist in this genre is a youth venturing into the adult world. When the students as readers have the same as age as the protagonists of the work being read, they will easily identify with and relate to the characters and their story.

The last requirement proposed by O'Sullivan for book selection of character education is that the books should offer a variety of cultures, allowing students to learn about the protagonists' experiences in the context of a particular culture. As explained in the subchapter discussing the definition of Bildungsroman, the genre has been enriched by works of both male and female authors and authors from the marginalized groups. This rich repertoire of Bildungsroman provides a great possibility for this genre to be used to teach character education, while getting students acquainted with and aware of the diverse cultures in the world. Furthermore, readers will be able to learn how different protagonists from different cultural backgrounds cope with their problems, and how their different backgrounds affect their ways of problem solving and decision making. Here, teachers or lecturers also play an important role in selecting books to be used for the particular purpose. Alternatively, it is highly recommended to negotiate with students on the titles of books to be used. College students naturally have particular interests in books, and teachers should be able to attend to their interest while at the same time catering to the requirements of character education.

The discussion has so far been concerned with the suitability of Bildungsroman to be used in teaching character education in a more general context. Now, it will turn to the Indonesian context.

\section{The Stories Can Help Students Identify and Reflect on the 18 Values Shaping Character Education Stipulated by the Department of National Education}

In Indonesian context, the Center for Curriculum of Department of National Education (2010, p. 8) has stipulated 18 values that should shape character education, namely religiosity, honesty, tolerance, discipline, hard-work, creativity, independence, democratic, curiosity, nationalism, patriotism, appreciation for achievements, friendliness, love for peace, love for reading, environmental awareness, social awareness, and responsibility. These values can be regarded as universal values, for character education, regardless of the geographical boundaries, is in general aimed at cultivating the above character traits. This statement is attested to by O'Sullivan (2004, p. 640), who stated that "society is in general agreement about what constitutes a good character trait. In fact, numerous published lists of virtues are remarkably similar in content." The universality of good character traits or virtues can be equated to the nature of Bildungsroman that aims to educate readers across different cultural and national backgrounds.

To buttress this argument, two examples of how certain Bildungsroman works contain the above traits will be given. The classical work of Jane Eyre (1847), agreed by many as one of the best English Bildungsroman provides a rich source of character traits, such as religiosity, honesty, discipline, hard work, creativity, independence, and curiosity. Jane, who is an orphan with no loving family members to support and take care of her, has to survive the hardship that she faces early in her life. Her education at Lowood restores her faith in God and changes her previously one-sided view of the world; in other words, her religiosity is restored while being able to maintain a balance life in the spiritual and worldly realms. It is her honesty, discipline, hard work, and creativity that makes her survive the harsh life in Lowood and her curiosity as well as 
independence that prompts her to venture into the professional world as a governess.

In Indonesian literature, Laskar Pelangi (2005) will be able to teach readers almost all of the 18 character traits mentioned above. To be more specific, the youth characters in Laskar Pelangi, who come from a remote place in Indonesia and lower economic background, present readers with the hardship of remote area's students in gaining better education and better life in general. Interestingly, notwithstanding all the limitations, especially in access to science and technology, the protagonists can be successful in their studies, to the extent that their achievements exceed the students from the upper class school. Their creativity also leads them to win a competition that has always been won by the most favorite and expensive school in their area. The protagonists clearly show many of the character traits listed by the Department of National Education from which readers can learn and cultivate their own.

\section{CONCLUSION}

It is important to bear in mind that character education is a life-long process; it takes place regardless of time and place. In academic context, character education is also necessary to be administered in college or higher education by means of integration with other subjects, including and ultimately with literature. The present study has offered Bildungsroman as one of the genres most suitable for teaching character education to college students due to its characteristics as a novel of education with young adult protagonists intended at young adult readers.

Character education in college is a continuation and strengthening/consolidation of the character education in the previous schools and the character students have developed elsewhere previously. In the same vein, Bildungsroman deals with maturation process that usually starts from childhood/adolescent to which college students can relate to by reflecting on their own past experiences (decision making, problem solving), past attitudes, past behaviors, and how all of them have shaped who they are today, and whether changes are necessary for their present character.

In the case of character education, it is not solely the genre or book that has to be considered carefully, special attention should be given to how the book is used to teach character education and how students "interact" with the book. In other words, it is the processes of the students reading the book that is more important. Hence, as this study focuses on the exploration of the potentials of Bildungsroman serving the teaching of character education, future researchers are encouraged to analyze and explore effective ways of teaching character education to college students through this genre.

\section{REFERENCES}

Au, J. (2011). The Bildungsroman genre: Defining the old, the new, and the same. Retrieved from https://ja00785.files.wordpress.com/2011/04/ess -final-research-paper-52.pdf.

Brown, J. P. (2013). The moral scope of the English Bildungsroman.' In Lisa Rodensky (ed). The Oxford Handbook of the Victorian Novel (pp.
663-678). Oxford: Oxford University Press. https://doi.org/10.1093/oxfordhb/978019953314 5.013.0032.

Bronte, C. (1847). Jane Eyre. The Pennsylvania State University: Electronic Classics Series. Retrieved from http://www2.hn.psu.edu/faculty/jmanis/bronte/Ja ne-Eyre6x9.pdf

Brynildssen, S. (2002). Character education through children's literature. ERIC Digest, 63. Retrieved from www.eric.ed.gov.

Buckley, J. H. (1974). Season of Youth: The Bildungsroman from Dickens to Golding. Cambridge, Mass.: Harvard University Press. https://doi.org/10.4159/harvard.9780674732728.

Chang, L. P., En, Y. C., \& Yi, H. Y. (2011). A Native American girl's coming of age in Louise Erdrich's The Porcupine Year. World Journal of English Language, 1(2), 43-51. https://doi.org/10.5430/wjel.v1n2p43

Boes, T. (2006). Modernist studies and the Bildungsroman: A historical survey of critical trends. Literature Compass 3(2), 1-14. https://doi.org/10.1111/j.1741 4113.2006.00303.x

Boes, T. (2008). Apprenticeship of the novel: The Bildungsroman and the invention of history, ca. 1770-1820. Comparative Literature Studies 45(3), 269-288. https://doi.org/10.1353/cls.0.0047

Bohlin, K. E. (2005). Teaching character education through literature: Awakening the moral imaginations in secondary classrooms. Oxon, New York: RoutledgeFalmer. doi: https://doi.org/10.4324/9780203299838.

Dharmawan, N. S. (2014). Implementasi pendidikan karakter bangsa pada mahasiswa di perguruan tinggi (implementing national character education to college students). Paper presented at Pembinaan Pendidikan Karakter bagi Mahasiswa PTS di Lingkungan Kopertis Wilayah VIII.

Drabble, M. (ed). (2000). The Oxford companion to English literature: Sixth edition. Oxford: Oxford University Press.

Farida, I. (2012). Model pendidikan karakter di perguruan tinggi: Langkah strategis dan implementasinya di universitas (A model of character education in universities: Strategic steps and its implementation in universities). Jurnal IImiah Administrasi Publik dan Pembangunan, 3(1), 445-452.

Gunarti, A. S. (2013). Penerapan pendidikan karakter melalui pembelajaran sastra. NOSI 1(1),54-59.

Ikhwan, W. K. (2013). Upaya menumbuhkan karakter anak dalam pembelajaran sastra anak dengan model play-learning dan performance-art learning di (Efforts of growing children's characters in children's literature instruction with play-leaning and performance-art learning in) SDN Banyuajuh 4. Widyagogik, 1(1), 70-84.

Inderawati, R. (2012). The development of literary appreciation instrument in building students' character. Sino-US English Teaching, 9(2), $937-$ 945.

Iversen, A. T. (2009). Change and continuity: The Bildungsroman in English (Unpublished PhD Dissertation). University of Tromsø, Norway. 
Kanzunnudin, M. (2012). 'Peran sastra dalam pendidikan karakter.' Prosiding Seminar Sastra, 195-204.

Klein-Ezel, C. et al. (2014). Character education using children's literature, puppets, magic tricks, and balloon art. International Journal of Humanities and Social Science, 4(14), 1-15.

Kuh, G. D. \& Paul D. U. (2004). College and character: Insights from the National Survey of Student Engagement. New Directions for Institutional Research, Assessing Character Outcomes in College 122, 37-54. https://doi.org/10.1002/ir.108.

Kusmarwantini. (2012). Menumbuhkan karakter anak melalui pembelajaran sastra di sekolah dasar (Growing children's characters through literature instruction in primary schools). Paper presented at The National Seminar and Alumni Meeting of the $48^{\text {th }}$ Anniversary of UNY. Indonesia: Yogyakarta State University, May.

Lickona, T. (1991). Educating for character: How our school can teach respect and responsibility. NewYork City: Bantam.

Ministry of National Education. 2010. Developing cultural education and national charactersschool guidelines. Jakarta: Department of Research and Development.

Nurgiyantoro, B. (2010). Sastra anak dan pembentukan karakter. Cakrawala Pendidikan, 25-40.

Olaniyan-Shobowale, K.O., Jimoh, A.S. \& Shittu, R. (2016). A Study of the inculcation of moral values using prose literature-in-English among senior secondary school students of Ewekoro Local Government Area of Ogun State. IOSR Journal of Humanities and Social Science (IOSR-JHSS), 21(11), 15-20.

O'Sullivan, S. (2004). Books to live by: Using children's literature for character education. The Reading Teacher, 57(7), 640-645.

Parker, K. L. \& Ackerman, B. E. (2007). Character education in literature-based instruction. Faculty Publications and Presentations, 33. Retrieved from http://digitalcommons.liberty.edu/educ fac pubs /33.

Prestwich, D. L. (2004). Character education in America's schools. The School Community Journal, 139-150.
Ripai, A. (2012). Pengembangan teknik berpikir berpasangan berbagi pembelajaran menulis teks drama yang bermuatan nilai-nilai pendidikan karakter pada mahasiswa pendidikan bahasa dan sastra Indonesia (Developing think-pair-share technique in the instruction of play script writing containing character education values to students of Indonesian language and literature education). SELOKA Jurnal Pendidikan Bahasa dan Sastra Indonesia 1(2), 151-156. Retrieved from http://journal.unnes.ac.id/sju/index.php/seloka

Ryan, K \& Bohlin K. E. (1999). Building character in schools: Practical ways to bring moral instruction to life. San Francisco: Jossey-Bass.

Schwartz, A. J. (2000). It's not too late to teach college students about values. The Chronicle of Higher Education, 46(40), 68.

Silay, N. (2013). Character education for university students'. European Journal of Educational Studies 5(1), 111-120.

Sojourner, R. J. (2012). The rebirth and retooling of character education in America. McGraw-Hill Research Foundation. Retrieved from www.mcgraw-hillresearchfoundation.org

Summerfield, G. \& Lisa D. (eds). (2010). Introduction. In New Perspectives on the European Bildungsroman (pp. 1-10). New York: Continuum International Publishing Group.

Susanti, R. (2013). Penerapan pendidikan karakter di kalangan mahasiswa (Implementing character education to college students). Jurnal Al-Ta'lim, 1(6), 480-487. https://doi.org/10.15548/jt.v20i3.46

Sweeney, L. (2008). The case for character education. Shawnee Mission, KS: Marsh Media.

Tighe, M. A. (1998). Character education + young adult literature $=$ Critical thinking skills. The Allan Review 26(1), 57-63. https://doi.org/10.21061/alan.v26i1.a.12.

Tyra, C. (2012). Bringing books to life: Teaching character education through children's literature. Rising Tide, 5, 1-10. Retrieved from http://web1.smcm.edu/educationstudies/EdStudi es\%20MAT\%20Rising\%20Tide/volume-5.html.

Watz, M. (2011). An historical analysis of character education. Journal of Inquiry and Action in Education 4(2), 34-53. 